\section{"Tradition", person, gender, and STD/HIV/AIDS in southern Mozambique}

\author{
"Tradição", pessoa, gênero e DST/HIV/AIDS no Sul \\ de Moçambique
}

\author{
${ }_{1}$ Instituto de Filosofia \\ e Ciências Humanas, \\ Universidade Estadual de \\ Campinas, Campinas, Brasil. \\ 2 Centro de Estudos \\ Africanos, Universidade \\ Eduardo Mondlane, Maputo, \\ Moçambique. \\ Correspondence \\ L. H. Passador \\ Programa de Pós-gradu- \\ ação em Antropologia \\ Social, Instituto de Filosofia \\ e Ciências Humanas, \\ Universidade Estadual de \\ Campinas. \\ Rua Dr. Olímpio da Paixão \\ 13, Atibaia, SP \\ 12940-770, Brasil. \\ passador@unicamp.br
}

\begin{abstract}
In southern Mozambique, the "traditional" notion of personhood is constructed through a process, as an outcome of diachronic and synchronic social relations that encompass kin and other peers, including spirits. Both person and body are thought of as elements traversed and determined by these relations, which include the gender relations whose complementarity finds expression in alliances and the production of descendants. In this system of agnatic kinship, descent is possible through women, who produce the male and female persons. Because of women's structural position, they may be suspected of fostering deconstruction of the person as well, with diseases providing the objective data that ground such a charge. To a certain degree, HIVIAIDS has been experienced in terms of this sociocultural arrangement, which defines disease as the result of action by social subjects that jeopardizes the person, placing women in the vulnerable position of being seen as the producers of disease. This has defined the ways in which people experience both the epidemic as well as STD/HIVIAIDS prevention and treatment messages and public policies.
\end{abstract}

Interpersonal Relations; Acquired Immunodeficiency Syndrome; Sexually Transmitted Diseases; Africa
Luiz Henrique Passador 1,2

Based on data from an ethnographic study, the article explores the role of "tradition" in southern Mozambique and its implications in combating the HIV/AIDS epidemic. The discussion encompasses the notions of personhood, gender, and disease, their implications as far as social responses to HIV/AIDS, and how these notions and responses relate to models and public policies for controlling the epidemic. I first analyze what is identified as "tradition", what components define the notions of personhood and gender in the area under research, and how they relate to the universe of disease. Lastly, I explore the efficacy of the models adopted in HIV/AIDS policies in Mozambique.

With the advent of the HIV/AIDS epidemic, "tradition" became one of the focal points in Mozambique in discussions and public policy initiatives intended to control the disease. Both governmental and nongovernmental agencies and organizations have engaged in debate and activities revolving around the population's reliance on traditional medicine, kinship and gender relations, and sexualities, which are associated with a universe identified as "traditional" and seen as fostering vulnerability to STDs and HIV/AIDS.

Historically, the debate on "tradition" and its ability to hamper both colonial and post-colonial "modernization" projects has pervaded political debate and social thought in Mozambique. In this sense, the current epidemic has simply stirred yet another round of discussion about what is called 
"tradition" and the issues it raises in the realm of the State and of public policy, including healthcare policy. In Mozambique, "tradition" is not only a cultural and behavioral phenomenon but also a political, social, and economic one - one that even plays a crucial role in the dynamics of civil war 1,2,3. My use of quotation marks to set off the words "tradition" and "modernity" therefore serves to indicate that these terms are seen more as discursive and historical constructs than as objectively identifiable facts. In other words, given this historical picture, the terms "tradition" and "modernity," more than analytical concepts within an academic and political debate, or more than exogenous moral values, have become emic categories, present in daily discourse and common sense. It should be underscored that this analysis refers to what subjects identified as "traditional" and "modern" within their own particular reality. Although I focus more on cultural questions, it must be said that this sphere is neither detached nor disconnected from others that ground social responses to HIV/AIDS in Mozambique.

\section{Research methodology and context}

This qualitative, ethnographic research study was conducted in the Homoíne District, Inhambane Province, in southern Mozambique, with participatory observation during June 2007 through February 2008. Homoíne has a population of 110,475 (56.2\% female) 4 , with the vast majority living in the rural area (93\%) 5 in poor housing and engaging in family agriculture as their main economic activity 5 . Historically, the district has provided male migrant labor to South Africa (miners, civil construction workers, workers in commerce, etc). The local economy depends primarily on women in agricultural production and commerce. There is only one secondary school in the district and the illiteracy rate is $41 \%$ among men and $62 \%$ among women 5 . Only $1 \%$ of the population has access to electricity 5 , while water and sewer services are available solely in the central village, that is, at the Healthcare Center, Administrative Palace, Catholic mission, and teacher training center. There is only one Healthcare Center in the central village and another 10 Healthcare Posts in the interior, which is not enough to cover the entire area. During fieldwork, only one foreign physician (a woman) was working in the district, coordinating an international aid NGO's work with HIV-positive patients. Patient care was provided almost solely by nurses and medical and healthcare assistants. A significant portion of the population, especially in the interior of the district, found access to healthcare facilities problematic. For this reason, "traditional" midwives were made part of the service, referring pregnant women, parturients, mothers, and babies from distant locations to the Healthcare Center, where they could receive STD/HIV/ AIDS testing and assistance. According to official epidemiological data 6 , the HIV/AIDS rate in the $15-49$ age bracket is $12 \%$ in the Province of Inhambane, the majority being women (there are no data available for Homoíne). As in the rest of Mozambique, the epidemic has a female profile in this region, with transmission mostly through heterosexual relations.

There are major differences between southern, central, and northern Mozambique owing to the cultural specificities of the country's ethnolinguistic groups and to the diversity of colonial and post-colonial experiences and wars in each region. The data in the present study refer only to the district where the research was conducted and can at most be extended to southern Mozambique, which is reasonably homogenous in historical and cultural terms 7. Research took place in a predominantly rural area, which is of significance against a backdrop of historical divisions between rural and urban universes - a phenomenon that Mahmood Mamdani 8 argues is structural on the African continent. The dynamics of civil war were distinct in rural and urban areas and still impact daily life sixteen years after the 1992 peace accord. The central village of Homoíne was the setting for the largest massacre in the war, in 1987, and the interior of the district sheltered a vital base of RENAMO (Mozambique Resistance Movement), which fought in opposition to FRELIMO (Mozambique Liberation Front). These historical events brought about displacement, transformations, and losses of life and infrastructure, leading the previously prosperous district to collapse, with the local population still enduring hardships today.

\section{The realm of "tradition" in southern Mozambique}

In order to understand the implications of "tradition" within the current AIDS epidemic and how it impacts the population's vulnerability to STDs and HIV, it is first necessary to clarify some crucial points that will establish what is meant by "tradition," how it defines the notion of personhood in the area under research, and how it relates to gender relations and the universe of disease.

What is referred to as "tradition" encompasses a vast universe that goes beyond a set of objects, habits, customs, and rituals; rather, it 
is a realm that is systematized by cosmologies, ontologies, and kinship and family systems that produce and lend order to social practices and worldviews. In terms of discourse, the notion of "tradition" is usually constructed through its complementary opposition to a universe identified as "modernity". In their comments, subjects always link the realm of "tradition" to the past, to a remote space, and to a sociocultural otherness. When referring to "tradition", subjects use expressions like "in those times", "in those places", and "those people" to delineate their analytical borders in terms of discourse, constructing difference markers that tie the universe of "tradition" to the mato (a term used to refer to the rural universe) while associating the city and its signs of urbanity with the realm of "modernity". If this appears to take the form of a dichotomy or contradiction at the level of discourse, in practice the boundaries between these two realms are not so sharp, nor are they mutually exclusive when their elements are visible. This can be seen in the central village of Homoíne, where there is a steady movement between city and mato, with these two universes constantly relating and interpenetrating, blending and merging; it becomes even more notable during critical moments, such as disease or death. In their relations with these events, subjects are forced into constant contact with and movement between "modernity" - characterized by biomedicine, its products, and its institutional spaces - and "tradition", which in daily speech is associated with witchcraft, the action of people and spirits, and curandeirismo (the practices of healers).

Disease always prompts speculation about its cause. During such processes, it is easy to perceive the contemporariness of traditional medicine, witchcraft, and local cosmology as elements that organize subjects' thoughts and actions, as they move between traditional medicine and biomedicine without necessarily sensing any contradiction. "Traditional" speculations about disease diagnosis inevitably involve the possibility of asking who caused the disease, as Helgesson has pointed out ${ }^{9}$, placing physical and body experience within the realm of interpersonal and social relations understood to be the "traditional" causative basis, even for diseases diagnosed and treated by biomedicine. One observes an ongoing potential to interpret and treat disease using both models, without tension between them or mutual exclusion. Furthermore, there is also an ongoing potential to encompass diseases diagnosed and treated by biomedicine and its agents within the notion of "traditional disease". As with other aspects of social life, in people's experiences with disease, "tradition" and "modernity" do not clash at the pragmatic level but only at the level of an a posteriori analytical discourse that endeavors to classify, systematize, and establish a hierarchy for such experiences within distinct realms, with a tendency to enfold "modernity" into "tradition". It is therefore necessary to understand what notions of personhood and body are operating in the realm of "tradition", for these define how subjects experience disease.

\section{Personhood, gender, and the universe of disease within the realm of "tradition"}

Personhood is, in brief, defined in part by one's descent group, with a person maintaining a constant relationship with both dead and living ancestors, including grandparents, parents, siblings, children, and grandchildren, which may be agnatic (of patrilineal descent, although it should be noted that in this region the lineages do not extend over many generations), matrilateral, or madodas ("big men", including non-kin). A person is incomplete if he is not linked to a descent group and if he does not produce any descendants. In terms of alliances and matrilaterality, a person is incomplete if he doesn't marry, has no sograria (the spouse's kinship group), and has no sons-in-law, daughters-in-law, and consequent affines. Kinship relations define a vital realm in a person's life, and alliances extend into non-family forms, like relations with neighbors and xarás (which Webster 10 has classified as quasi-kin), in addition to church relations, friendships of varying degrees of formality, and a person's position and relations in the working world. So alliances in southern Mozambique go beyond matrimonial alliances and beyond the kinship circle. This set of descent relationships and alliances defines a person, and the construction of this network is a subject's chief investment in defining his social existence. This model of personhood, which conjoins diachronic and synchronic relationships, is represented in Figure 1.

This array of relations reflects the life trajectory and accumulation of social equity of a person, who, following his death, will define his status in the spirit world and his relations with those living. Their social equity defines men and women while alive and is transferred to their existence as dead ancestors. The process of constructing personhood therefore defines a person as a being undergoing a constant process of construction, even beyond the world of the living, quite similar to Comaroff's analysis 11 of the Tswana. In short, a person is a project that is only completed when he passes away, becoming an ancestor who is 
Figure 1

Model of personhood.

DEAD ANCESTORS

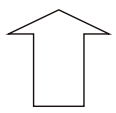

LIVING ANCESTORS/MADODAS

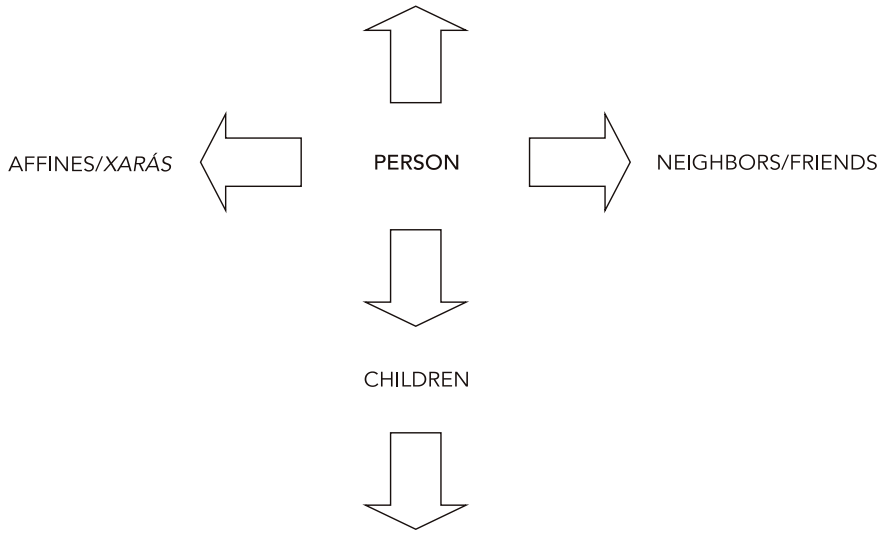

GRANDCHILDREN remembered and respected by his descendants, with the duty to protect his kinship group and to intervene when the expected order is ruptured by its members or by the action of extra-kinship elements. Likewise, the person should be remembered by his neighbors and wider community as someone who forged respectable alliances and broader relations, thereby extending his influence and power beyond the descent group. Name, family, and land are expanded to the extent that the person expands through descent and alliances, making these inseparable components of his personhood. Whoever inherits these also inherits the person's socially recognized "grandeur". Despite some historical transformations, the contemporary construction of personhood proves quite similar to what was observed in late nineteenth-century life 7 and is now present in realms associated with "modernity" - State and market, for example.

The present study found this to be the root of the persistence of so-called "traditional" pragmatism within an environment that has incorporated "modern" elements. Within this context marked by a certain "modernity", personhood is still constructed according to the logic of an enduring and encompassing "traditional" ontology defined by the elements described above; various objects, signs, and processes are manipulated in order to recreate a social order in which the person can recognize himself and be recognized by his peers. While "modern" components may be observed within this reality, it is the "traditional" person who constructs it, replacing his ontology on a seemingly promiscuous mixture of "traditional" and "modern" elements. Social reality is constantly reconstructed by the logic of the construction of personhood through the manipulation of these elements, without this requiring that habits and customs objectively recognized as "traditional" still persist. Personhood is not defined by the materiality and objectivity of these habits and customs per se but by the way in which a person orders and reorders them, invents and reinvents them, through this interaction of multiple elements recreating an ontological, pragmatic unity coherent with the presuppositions and principles that define the person, as much as they define the recognized relational reality.

In this social scheme, personhood is deconstructed by interrupting the flow of relations that originally established personhood. This is why diseases may be experienced as the symptoms of deconstructive activities initiated by peers. The focus of disease is not the body but the interpersonal and social relations which traverse bodies. This logic leads subjects to conceptions that attribute "traditional diseases" to witchcraft, spirit action, the breach of social norms, and anti-social acts. If the constructive basis of personhood lies in relations of social proximity, the diagnosis for deconstruction (reflected in illness or death) is to be found in conflicts and breakdowns in these relations. This is why most accusations of witchcraft, which link a disease with socially rooted maleficence, target the subjects who are socially closest, i.e., kin and neighbors.

Defined by agnatic descent and by alliances, in southern Mozambique the family can only be constituted by incorporating women through matrimonial alliances that will produce descendants. Structurally, it is up to women to ensure the continuity of a nuclear family and of the people constructed within it. This lends women an ambiguous gender condition: while on the one hand they guarantee construction of the family, and of male and female persons, they also have the power to deconstruct them. Herein lies the root of the accusations of witchcraft and maleficence that are almost always aimed at women. When we speak about a logic defined by kinship, we must recognize that the logic of gender and 
of generation is what rules when this ambivalent power is assigned. This is why older women are more vulnerable to accusations of maleficence. It is also why there is a structural tension between daughters-in-law and mothers-in-law: these women struggle over legitimacy within a descent group of which they became members through alliance, meaning they may always find themselves suspected of favoring the families they came from. They are always vientes, a term used to refer to those who come from outside. In polygamous marriages, which are common in the area, conflicts also extend to a husband's multiple spouses, who refer to each other as rivália and often accuse each other of witchcraft. Accusations between wives and between daughters-in-law and mothers-in-law usually involve cases of disease or death of a husband or child or of failures with machambas (crops that are most generally produced by the family, under the duty of women). In other words, they involve the female realms of production of descendants and of subsistence.

In this context, "traditional" diseases are in large part blamed on women's actions and linked to their sexuality, body, and bodily fluids, because they are linked to the conception and generation of descendants. Disease, as the experience of deconstruction of personhood, is largely seen as an initiative of women, who are responsible for its construction. Georges Balandier 12 has argued that this situation is structural in a number of areas of the African continent, where women are seen as "the dangerous half". So the female is not a disempowered realm within "tradition"; rather, the power attributed to women lies at the root of many fears, both of men and of other women.

\section{HIV/AIDS in the face of "tradition"}

In this context, the HIV/AIDS experience can be logically and rationally interpreted in accordance with the premises of "traditional" diseases, as mentioned earlier 13. This explains the relations that many of the observed subjects have established with HIV/AIDS: on the one hand, they tend not to recognize its specificity; on the other, they actually doubt or even deny its very existence, interpreting it through conceptions of "traditional" diseases. Within the observed context, it is a logical, plausible possibility that a disease linked to sexuality, to the exchange of bodily fluids, and to a set of non-specific signs and symptoms could be viewed as a "traditional" disease. This holds even truer if we bear in mind that HIV/AIDS is a disease marked by the presence of foreigners and vientes, woven into a universe further marked by money from international cooperation agreements; this situation may create an association between the disease and ambition and may conjure up a universe of suspicions surrounding the possible use of scarce resources to obtain benefits, which serve as some of the main triggers of accusations of witchcraft and as fuel for mistrust.

Contributing to this are certain prevention policies centered on "behavioral changes", which shift the medical discourse into the realm of moral discourse in treating the disease. The ABC model (abstinence, being faithful and condom use), which in recent years has been an important paradigm in these policies in Mozambique, crystallizes the notion of a behavioral disease associated with improper, censurable behavior. Shaping the general lines of STD/HIV/AIDS prevention initiatives promoted by international agencies, this three-pronged approach casts abstinence and faithfulness as preferable to condom use and as a more effective means of prevention. These arguments reiterate a moral model already in place in the field of "tradition", reinforcing the notion that the disease is an event related to improper acts and to the breach of behavioral norms. Instead of standing in contrast with "tradition", the ABC approach reaffirms some of its values regarding sexuality and enforces the logic of "traditional" diseases: that these diseases are linked to socially condemned relations that render people vulnerable. This is why the ABC discourse finds no resistance among the population. Such policies have in fact renewed and revalidated the notions of risk behavior and risk groups, defined by moral behavior and judged in terms of trustworthiness. They downplay the efficacy of condom use, making it a priority only in prevention initiatives targeting groups considered "more vulnerable populations", like sex workers and truckers; in practice, they make the condom into a marker of difference and degree of trustworthiness for sexual partners, reaffirming the connection between these evils and "traditionally" stigmatized categories (truckers are vientes and prostitutes are promiscuous, "impure" women). They do little to help deconstruct the myths surrounding condoms - like the idea that imported condoms have been contaminated with HIV - thereby reinforcing mistrust of vientes and foreign evils. In identifying some of the factors that helped construct this idea, James Pfeiffer 14 has pointed to the social marketing strategies used to promote the Jeito condom as the origin of these rumors in the region of Chimoio. This all contributes to the ineffectiveness of primary, non-medication prevention policies centered on the use of condoms, and suggests there is a tendency to medicalize 
epidemic initiatives, which include the prevention of vertical transmission and antiretroviral treatment, both available in Homoíne through the public health network since 2004 .

Within this picture, women display a specific kind of vulnerability. First, in the "traditional" model, they are recognized as doers of maleficence and the carriers of impurities that cause disease, especially in the realm of sexuality, and they are the object of constant mistrust. By reaffirming a moral logic, prevention messages effectively allow women to be seen as people who should not be trusted, because they are "traditionally" viewed as potential transmitters of diseases via sex. Women who demand the use of a condom run the risk of being marked as promiscuous, not very trustworthy, and associated with risk groups.

Second, under the "traditional" model, women who do not produce children or who produce stillborns are devalued and accused of being responsible for this maleficence. Having children and producing descendants is necessary to a woman's social security. This notion explains a significant fact reported by two foreign women doctors during the present research study in the Province of Inhambane: a relatively high proportion of HIV-positive pregnant women participate in initiatives to prevent vertical transmission, while fewer take part in antiretroviral treatment following birth, suggesting a tendency towards medicalization of prevention itself, undermining condom use. The women try to ensure their pregnancy goes well and their children will be born healthy, starting them off in the world as valued people and protecting themselves from any accusations by husbands, mothers-in-law, and riválias. In this case, taking care of oneself has much more to do with taking care of one's descendants and the stability of alliances than taking care of one's own body, decreasing these women's participation in antiretroviral treat- ment. Furthermore, if they continue medical treatment, it may mark them as impure and stigmatize them as transmitters of maleficence, unable to produce descendants because they are HIV-positive. This prompts some mothers-in-law to kick their daughters-in-law out of the house - a regular occurrence and the target of official campaigns, with posters tacked up throughout public healthcare facilities.

In terms of prevention, the contraceptive nature of condom use during sexual relations puts the device at clear odds with the demand to produce children and descendants, forcing a woman to choose between living without children or dying and leaving descendants behind; this dilemma is crucial to a person's social existence in southern Mozambique and a prime problem within the setting of a heterosexual epidemic.

"Traditional" notions of personhood, gender, and disease certainly contribute to leaving women more vulnerable to STD/HIV/AIDS. However, "tradition" is also something of an obligation in contexts where public health services are extremely limited and hard to access, in consequence of colonialism and the civil war in the area under research. This does not mean that "traditional" conceptions and structures would no longer operate in an environment of complete "modernity", where public health services were broadly available and easy to access. The history of Mozambique is characterized by constant articulation between and mutual transformation of what is identified as "tradition" and "modernity", with "traditional" forms persisting despite efforts to "modernize" the country. There is no reason to believe that the experience with the HIV/AIDS epidemic would be different, or that the dilemmas to be faced by "modern" Western biomedical models would be any less complex or paradoxical. 


\section{Resumo}

No Sul de Moçambique, a noção "tradicional" de pessoa constrói-se numa perspectiva processual, como fluxo de relações sociais diacrônicas e sincrônicas que congregam parentes e outros pares, inclusive os espíritos. Pessoa e corpo são pensados como elementos atravessados e determinados por essas relações, que congregam as relações de gênero em termos de complementaridade realizada nas alianças e produção da descendência. Num sistema de descendência local,é através das mulheres que a filiação e a descendência são possiveis, gerando a pessoa masculina e feminina. Essa posição estrutural as coloca sob suspeitas de promoção da desconstrução da pessoa, sendo as doenças percebidas como dados objetivos que apontam para tal ação. Em certa medida, o HIVIAIDS tem sido experimentado nos termos dessa disposição sócio-cultural que define as doenças como ações de sujeitos sociais que colocam em risco a pessoa, construindo uma situação de vulnerabilidade das mulheres ao estabelecê-las como promotoras de doenças. Tal cenário tem determinado as experiências que os sujeitos têm com a epidemia e com os discursos e políticas públicas de prevenção e tratamento das DST e HIVIAIDS.

Relações Interpessoais; Síndrome de Imunodeficiência Adquirida; Doenças Sexualmente Transmissíveis; África

\section{References}

1. Geffray C. A causa das armas: antropologia da guerra contemporânea em Moçambique. Porto: Edições Afrontamento; 1991.

2. Cahen M. Os outros: um historiador em Moçambique, 1994. Basel: P. Schlettwein Publishing Switzerland; 2004.

3. Honwana AM. Espíritos vivos, tradições modernas: possessão de espíritos e reintegração social pósguerra no Sul de Moçambique. Maputo: Promédia; 2002.

4. Instituto Nacional de Estatística de Moçambique. III recenseamento geral da população e habitação. População da Província de Inhambane. http://www.ine.gov.mz/censo2007/rp/pop07 prov/inhambane (accessed on 02/Oct/2008).

5. Ministério da Administração Estatal. Perfil do Distrito de Homoíne - Província de Inhambane. Maputo: Ministério da Administração Estatal, República de Moçambique; 2005. (Série Perfis Distritais).

6. Portal HIV/SIDA Moçambique. Divulgação de dados de vigilância epidemiológica do HIVRonda, 2007. http://www.sida.org.mz/index. php?option $=$ com_docman\&task=view_category\& Itemid $=70 \&$ subcat $=1 \&$ catid $=20 \&$ limitstart $=0$ \&lim it $=5 \&$ jos_change_template $=$ pages-template $($ accessed on 02/Oct/2008).

7. Junod HA. Usos e costumes dos Bantu, tomos I e II. Maputo: Arquivo Histórico de Moçambique; 1996. (Série Documentos, 3).
8. Mamdani M. Citizen and subject: contemporary Africa and the legacy of late colonialism. Princeton: Princeton University Press; 1996.

9. Helgesson A. The Tshwa response to Christianity [Masters Thesis]. Johannesburg: Faculty of Arts, University of Witwatersrand; 1971.

10. Webster DJ. Agnation, alternative structures, and the individual in Chopi society [Doctoral Dissertation]. Grahamstown: Faculty of Arts, Rhodes University; 1976.

11. Comaroff J, Comaroff J. On personhood: an anthropological perspective from Africa. Social Identities 2001; 7:267-83.

12. Balandier G. Antropo-lógicas. São Paulo: Editora Cultrix/Editora da Universidade de São Paulo; 1976.

13. Passador LH, Thomaz OR. Raça, sexualidade e doença em Moçambique. Revista Estudos Feministas 2006; 14:263-86.

14. Pfeiffer J. Condom social marketing, Pentecostalism, and structural adjustment in Mozambique: a clash of AIDS prevention messages. Med Anthropol Q 2004; 18:77-103.

Submitted on 25/Aug/2008

Final version resubmitted on $07 /$ Oct $/ 2008$

Approved on 04/Nov/2008 